\title{
Kolanjiyokarsinom ile karışan rekürren piyojenik kolanjit
}

\section{Recurrent pyogenic cholangitis involved in cholangiocarcinoma}

Mesut AYDIN ${ }^{1}$, Burak SUVAK ${ }^{1}$, Ahmet Cumhur DÜLGER ${ }^{1}$, Abdussamet BATUR ${ }^{2}$, Dilek ERSIL SOYSAL ${ }^{3}$, Mahmut ARABUL ${ }^{4}$

Yüzüncü Yıl Universitesi Tip Fakültesi, ${ }^{1}$ Gastroenteroloji Bilim Dall, ${ }^{2}$ Radyoloji Anabilim Dall, Van,

Katip Çelebi Üniversitesi, Atatürk Eğitim Araştırma Hastanesi, ${ }^{3}$ Iç Hastalıları Anabilim Dal, ${ }^{4}$ Gastroenteroloji Bilim Dal, Izmir

Rekürren piyojenik kolanjit, sosyoekonomik düzeyi düşük toplumlarda daha sık görülen, etyolojisi tam bilinmeyen fakat düşük protein içerikli beslenme, paraziter enfestasyonlar gibi faktörlerin suçlandığı, safra yolu destrüksiyonu, striktürler, tekrarlayan taş oluşumu ve kolanjit atakları ile seyreden ve bazen maligniteler ile karışabilen bir hastalıktır. Bu olgu sunumunda kolanjiyokarsinom ön tanısı ile takip edilen ve rekürren piyojenik kolanjit olduğunu tespit ettiğimiz nadir rastlanan bir olguyu sunmayı amaçladık.

Anahtar kelimeler: Rekürren piyojenik kolanjit, kolanjiyokarsinom, ERCP
Recurrent pyogenic cholangitis is a disease that is more common in lower socioeconomic groups; its etiology is not well known, but factors such as a low-protein diet and parasitic infections are implicated. Recurrent pyogenic cholangitis is characterized by biliary tract destruction, recurrent stone formation, and cholangitis and is sometimes involved in malignancies. Here we aimed to present a case of a preliminary diagnosis of cholangiocarcinoma; however, we identified it in follow up as recurrent pyogenic cholangitis.

Key words: Recurrent pyogenic cholangitis, cholangiocarcinoma, endoscopic retrograde cholangiopancreatography

dokta kitlesel görünüm ve stent saptanarak tarafımıza sevk edilmiş. Muayenesinde batında yaygın hassasiyet, defans, rebaund ve Murphy pozitifliği mevcut olan hastanın rutinlerinde lökosit: 17000, C-reaktif protein: 130 (N:0-5), total/direk bilirubin:3/2,2, kanser antijen: 19-9: 61,68 (N:0-37), alkalen fosfataz ve gama glutamil transferazda hafif yükseklik dışında anlamlı bulgu yoktu. Hastaya kolanjiyokarsinom+akut kolanjit ön tanıları ile ERCP yapıldı. ERCP'de; papilden lümene doğru uzanım gösteren etrafı püy, safra çamuru ve milimetrik kalküller ile kaplı, uzunlamasına parçalanmış plastik $10 \mathrm{~F}$ biliyer stent izlendi. Stent forseps yardımı ile parçalar halinde çıkarıldı.Kontrast verilerek yapılan skopik değerlendirmede koledokta çok sayıda taş ile uyumlu imaj izlendi. Koledok balonla sıvazlandığında bol miktarda taş, püy ve doku artığı geldiği görüldü (Resim 1-2).

Işlem öncesi çekilen magnetik rezonans kolanjiopankreatografi (MRCP) (Resim 3)'de; "intra ve ekstrahepatik safra yollan dilate olup lümeni dolduran multipl sayıda hipointens kalkül-safra çamuru ile uyumlu görünümler mevcuttur (rekürren piyojenik kolanjit?)" olarak rapor edilip RPK tanısı konuldu. Takipte genel durumu düzelen hasta kontrole gelmek üzere taburcu edildi.

\section{TARTISQMA}

Rekürren piyojenik kolanjit, tekrarlayan kolanjit atakları ile seyreden ve intrahepatik pigment taşlarının eşlik ettiği bir has- 
talıktır. Hastalık 1930'larda tanımlanmış ve Hong Kong Hastalığı, Oriental Kolanjit, Oryental Enfestasyonal Kolanjit gibi farklı şekillerde adlandırılmıştır. Genellikle genç orta yaşlarda daha sik görülür. Beslenme bozukluğu olan sosyoekonomik düzeyi düşük toplumlarda daha sik görülür (2). Etyolojide Ascaris ve Cholonorchis sinensis gibi enfeksiyonlarin rol oynadığı düşünülmektedir $(3,4)$. RPK olan hastaların safra kültürlerinde en sik E. coli, psödomanas, klebsiella, proteus türleri ve anaeroblar üremektedir (4). Pigment taşlarının incelemesinde parazit kalıntı ve yumurtalarına rastlanması paraziter enfeksiyonların rolünü desteklemektedir. Bir diğer hipotez sosyoekonomik düzeyi düşük, beslenme bozukluğu olan topluluklarda tekrarlayan portal bakteriyemilerin bu hastalığa neden olduğudur (5). Parazitik enfeksiyonların safra yollarında yapmış olduğu fibrozis striktürlere,safra stazına ve piyojenik kolanjite yol açar. Böylece bilirubin ve kalsiyumun çökmesi ile kalsiyum bilirubinat taşları oluşur (6). Klinikte hastalar tekrarlayan ataklar halinde ateş, sarılık, titreme (Charcot triadı) gibi kolanjit semptomları ile başvururlar. Ataklar arasındaki süre haftalar, aylar, bazen ylllar olabilir. Hastalık tedavisinde amaç varsa akut atağı tedavi etmek, tekrarlayan atakları önlemektir. Akut tedavide sıvı desteği ve antibiyotik uygulanır. Medikal tedaviye yanıt alınamayan olgularda girişimsel tedavi yöntemleri (sfinkterotomi, stent, nazobiliyer drenaj) uygula-

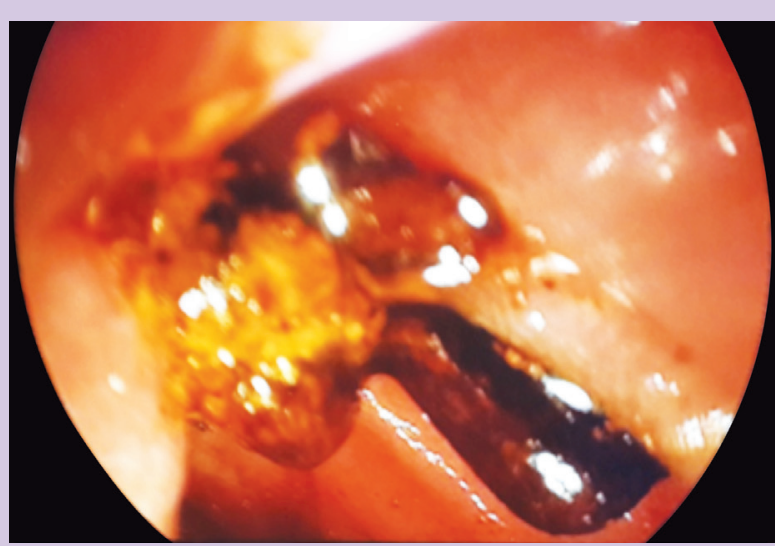

Resim 1. Parçalanmış etrafı taş ve püy dolu biliyer stent. nabilir. Tekrar eden atakları önlemek için ERCP ile taş-debris temizliği, striktürler için dilatasyon ve stent uygulamaları yapilabilir. Cerrahi olarak uygun olgularda sol lobektomi veya segmentektomi ameliyatları yapılabilir.

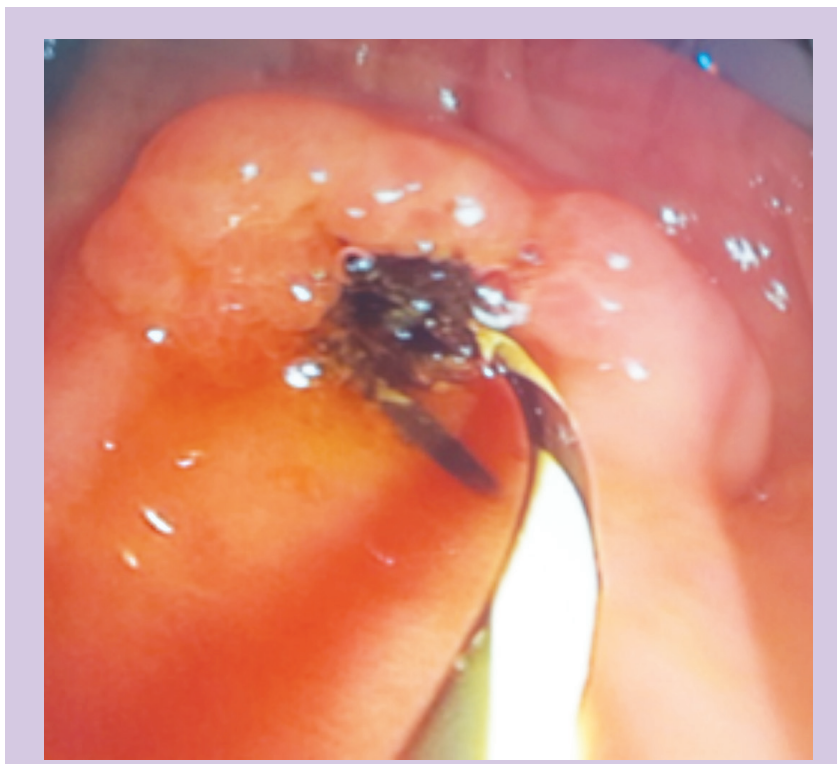

Resim 2. Stent çıkarılması ve balonla sıvama sonrası gelen debris.

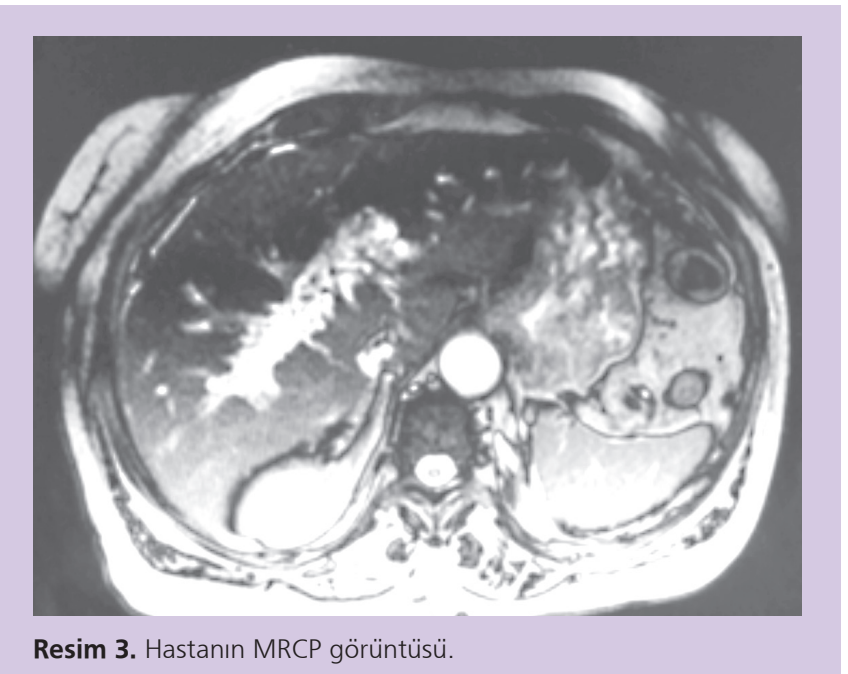

\section{KAYNAKLAR}

1. Lo C, Fan S, Wong J. The changing epidemiology of recurrent pyogenic cholangitis. Hong Kong Med J 1997;3:302-4.

2. Wen CC, Lee HC. Intrahepatic stones: a clinical study. Ann Surg 1972;175:166-7.

3. Lam SK, Wong KP, Chan PK, et al. Recurrent pyogenic cholangitis: a study by endoscopic retrograde cholangiography. Gastroenterology 1978;74:1196-203.

4. Seel DJ, Park YK. Oriental infestational cholangitis. Am J Surg 1983;146:366-70

5. Lim JH. Oriental cholangiohepatitis:pathologic, clinical an radyologic features. AJR Am J Roentgenol1991;157:1-8.

6. Khuroo MS, Zargar SA, Biliary ascariasis. A common cause of biliary and pancreatic disease in an endemic area. Gastroenterology 1985;88:41823. 